\title{
"Todos somos seres humanos completos"
}

Federico Montero $\mathrm{M}^{1}$

De acuerdo con el título que se le asignó a mi participación el día de hoy, yo debería hablar de prevención, de rehabilitación, de discapacidad, de calidad de vida, de adultos mayores, de todo eso y además, desde la perspectiva de los servicios de salud en Costa Rica. Cumplir con esa tarea resulta sumamente difícil sobre todo considerando el tiempo disponible para ello. En lugar de hacer una presentación informativa acerca de los enfoques que existen o no existen en el país con relación a los temas mencionados, desearía aprovechar esta oportunidad para hacer un enfoque que nos ayude a reflexionar acerca de dichos temas esperando con ello contribuir al cambio de paradigmas y a la eliminación de prejuicios que tan negativamente inciden en la situación de las personas con discapacidad en nuestra sociedad y en muchas otras sociedades del mundo.

Médico costarricense. Apdo: 845-1007.SJ.CR. fmontero@racsa.co.cr Conferencia dictada en la Universidad Estatal a Distancia de Costa Rica el 22 de marzo 2001 . 
El año pasado, 130 personas con discapacidad, padres y representantes de muchas organizaciones de veintisiete países de Europa, África, Australia y Norteamérica que conforman la Organización Mundial de Personas Discapacitadas se reunieron en Solihull, Reino Unido, para hablar de bioética y Derechos Humanos. Se trataba del primer encuentro de su género y allí se dio a conocer la Declaración de Solihull, de la cual les leeré algunos párrafos.

"Todos somos seres humanos completos. Creemos que una sociedad sin personas con discapacidad sería una sociedad más pobre. Nuestras singulares experiencias individuales y colectivas, constituyen una importante aportacion a la riqueza de una sociedad humana.

Exigimos el fin de la eliminación biomédica de la diversidad, la selección genética basada en criterios de mercado y la definición de normas y modelos por parte de personas no discapacitadas.

El cambio biotecnológico no debe servir de excusa para el control o la manipulación de la condición humana y la biodiversidad.

Sabemos que la única manera de asegurar un apoyo universal y el reconocimiento positivo de nuestras cualidades particulares consiste en exponer claramente nuestro derecho a la diversidad, con argumentos válidos, en una discusión abierta y democrática. Debemos formar alianzas con los científicos, los distintos profesionales sanitarios, eticistas, autoridades, defensores de los derechos humanos, los medios de comunicación y el público en general".

He considerado oportuno hacer referencia a esa Declaración, ya que el tema de la prevención de la discapacidad puede ser peligrosamente mal entendido o hasta aplicado. En nuestro país se habla poco de prevención de la 
discapacidad pero cuando se habla, no estoy muy seguro si existe uniformidad de criterios y claridad con relación a lo que ello significa.

Recientemente hemos oído bastante el concepto de prevención de la discapacidad con el Proyecto del "Centro para la Prevención de la Discapacidad" en el HNN. Entiendo que se trata del ya existente Centro de Tamizaje el cual se ampliará en sus alcances con el fin de realizar detección temprana de otras enfermedades las cuales con un tratamiento oportuno evitarán el desarrollo de daños irreversibles. Esto es importante y bueno, como lo es la vacunación o las campañas para prevenir accidentes laborales y de tránsito. Sin embargo, tanto en esta como en algunas otras circunstancias, el verdadero concepto de Prevención no es muy bien explicado. Pero independientemente de la conceptualización, lo verdaderamente importante es aquello que en algún momento expresó con bastante fundamento un reconocido activista en Derechos de las Personas con Discapacidad: "Aun con la prevención más sofisticada, detección temprana y servicios de rehabilitación, siempre habrá personas con discapacidades".

Efectivamente y para referirnos a un tema de gran vigencia e importancia, aunque la descripción del Genoma Humano nos ayuda a comprender muchas cosas y permitirá modificar o corregir ciertas cosas, al mismo tiempo nos ha ayudado a comprender que los seres humanos somos mucho más simples de lo que creíamos. Al mismo tiempo nos ha ayudado a comprender y a reconocer que esa simpleza es el producto de una gran imperfección, en donde difícilmente hay algún ser humano que no tenga alguna alteración en alguno de sus genes, en algunos casos muy evidentes y en otros muy sutiles, pero que al fin y al cabo se traduce en expresiones que son parte de la extensa biodiversidad. Lo único que está claro es que todos los seres humanos poseemos 
la misma cantidad de genes y que independientemente de la raza, la nacionalidad u otros factores; la conformación genética, es igual. Como dijo un Ministro de Cultura europeo el día que se dio a conocer el Genoma: "Hoy es un mal día para los racistas y los xenofobos".

Otro aspecto es el de la prevención de la discapacidad cuando estamos ante una enfermedad, una malformación o un trauma que ocasiona lesiones irreversibles. Ante estas situaciones, debemos actuar con todos los recursos disponibles con el fin de evitar que esas personas vean restringidas o limitadas la realización de sus actividades o su participación social, entendiendo por actividades: "la naturaleza y magnitud del funcionamiento a nivel de la persona" y por participación: la naturaleza y magnitud de la actuación de una persona en las situaciones de la vida en relación a las Deficiencias, Actividades, estados de salud y factores contextuales. Al igual que las actividades, la participación puede estar restringida en naturaleza, duración y calidad.

A través de acciones de rehabilitación en una primera instancia y de acciones anti-discriminación posteriormente, estaríamos garantizando el desarrollo de actividades en el primer caso y promoviendo la participación en el segundo. Pero estos conceptos establecidos por la Organización Mundial de la Salud presentan controversias entre sociólogos, profesionales de la salud y activistas en el movimiento de personas con discapacidad en donde estos últimos afirman: "desde nuestro punto de vista, es la sociedad la que nos discapacitada a las personas con deficiencia. La discapacidad es algo impuesto sobre nuestras deficiencias a través de que nosotros somos aislados y excluidos de la plena participación en la sociedad"

Desde el punto de vista de la rehabilitación y ahora sí, desde una perspectiva del campo de la salud, qué tenemos en nuestro país. Yo diría, aunque parezca paradójico, 
que tenemos mucho y muy poco. Mucho en el sentido de que las dos principales instituciones prestadoras de servicios de salud, cuentan con sendos servicios de rehabilitación médica, con muchos recursos técnicos y gran cantidad de personal formado y capacitado. Pero muy poco en cuanto a planificación, cobertura y recursos que garanticen los servicios en todas las regiones del país. Muy poco o nada en cuanto a investigación, muy poco en cuanto a provisión de ayudas técnicas, muy poco en cuanto a compromiso de las autoridades institucionales, muy poco en cuanto a decisión política para cumplir y hacer cumplir con lo establecido en la Ley 7600.

Sabemos que sólo un porcentaje muy pequeño de las personas con discapacidad requieren atención de alta complejidad y pienso que con una adecuada planificación de los servicios, esas personas podrían recibir una adecuada atención con los recursos actualmente existentes. El problema es que los servicios que se suponen de alta complejidad, en la actualidad dedican más de un $80 \%$ de su tiempo en la atención de situaciones que podrían atenderse y resolverse directamente en la comunidad o en los niveles intermedios de atención, con pocos recursos técnicos y recursos humanos medios con niveles de supervisión adecuados.

Debemos además recordar y aceptar que la rehabilitación es un proceso limitado no sólo en el espacio sino que también en el tiempo. Es únicamente un estado transitorio después del cual viene indudablemente el período más difícil que es el de la participación.

Y según algunos autores: "La calidad de vida dependerá de las posibilidades que tengan las personas de satisfacer adecuadamente sus necesidades humanas fundamentales".

Las necesidades humanas son: Finitas, Pocas e Identificables. La calidad de vida está en relación directa con la posibilidad de satisfacer las necesidades humanas fundamentales. 
Y si aceptamos que las PCD son "personas con las mismas necesidades fundamentales que cualquier otra persona pero además con necesidad de recursos especiales, para tener acceso a una misma calidad de vida", y si sabemos que las personas con discapacidad en Costa Rica no tienen en muchos casos acceso a esos recursos especiales (sillas de ruedas, vivienda adecuada, transporte y otras ayudas técnicas y servicios de apoyo), tenemos entonces que reconocer que lamentablemente, estas personas tienen en su gran mayoría una mala calidad de vida y estar de acuerdo con el último informe de la Defensoría de los Habitantes el cual ubicó a las PCD en el grupo de "los excluidos". Pero insisto, esa exclusión no es producto de sus características físicas, mentales o sensoriales, sino de la incapacidad de una sociedad y de un Estado para garantizar el pleno ejercicio de los Derechos Humanos a todos los habitantes. 